\title{
The Study on the Possibility of Using Ecological Materials with Antifungal Properties for Treating Natural Leathers
}

\begin{abstract}
OLGA NICULESCU*, CARMEN GAIDAU, DEMETRA SIMION, MARIANA DANIELA BERECHET
National Research and Development Institute for Textiles and Leather - Division Leather and Footwear Research Institute, 93 Ion Minulescu Str., Bucharest, Romania

Synthetic fungicides presently used are potentially harmful to both human health and for the environment. Recent research aims to fully or partially replace potentially toxic biocides with environmentally friendly materials. Esential oils extracted from plants may be an alternative to conventional fungicides. The purpose of the study was to investigate the possibility of using essential oil of cloves as alternative preservatives for skin treatment. Essential oil isolated from cloves (Eugenia caryophyllata) containing: eugenol - 78.03\%, aceteugenol - $10.93 \%$, caryophylene $-9.46 \%$. Following the study, it is concluded that the selected essential oil of cloves can be used as an antifungal agent in the field of natural leather processing.
\end{abstract}

Keywords: natural leather, gas chromatography mass spectrometry (GC/MS), FT-IR spectrometry, UV-VIS spectrometry, Aspergillus niger

Synthetic fungicides presently used are potentially harmful to both human health and for the environment and therefore, production and marketing is regulated and monitored continuously by European directives and regulations of the European Parliament and Council. There is no EU legislation in regulating specifically the content of chemicals in footwear and other leather products, but the use of chemicals is restricted by REACH (EC1907/2006) [1-4].

The use of pentachlorophenol leather industry has been banned on the toxicity of the compound, despite the fact that it has been used as a general antiseptic material in the industry.

Some countries have banned the use of polyhalogenated phenolic compounds.

2009 European Union Directive (2009/251/ EC) banned the use of dimethylfumarate (DMF).

In order to prevent the emergence and growth of microorganisms, biocides are used in various stages of leather processing, improving resistance to biological attack and preventing deterioration of mechanical and chemical properties of leather.

Biocides used in the leather industry have a certain toxicity to humans and the environment, some of which are prohibited by the directives in force (pentachlorophenol, polyhalogenated phenolic compounds).

Recent research aims to fully or partially replace potentially toxic biocides with environmentally friendly materials [5-10].

Essential oils are highly concentrated in biologically active compounds with different properties: antiseptic, antibacterial, immunostimulatory etc.

These can be used to protect against damage caused by fungi and bacteria.

Esential oils extracted from plants may be an alternative to conventional fungicides.

The biological activity of essential oils depends on their composition.

Essential oils that contain substituted phenols (eugenol, thymol, carvacrol, and guaiacol) exhibit strong antibacterial and antioxidant effects [11-15].

\section{Experimental part}

Materials and methods

- Cloves essential oil, Eugenia caryophyllata, (Adams, Romania) containing: eugenol - 78.03\%, aceteugenol $10.93 \%$, caryophylene $-9.46 \%$ and alpha humulene $-1.08 \%$ etc.

- Ethanol (Chemical Company, Germany), colorless liquid, boiling point $78.37^{\circ} \mathrm{C}$, density $-0.79 \mathrm{~g} / \mathrm{cm}^{3}$;

- The Box bovine leathers natural grain assortments, mineral tanned and wet finished by retanning, fatliquoring and dyeing (1.2-1.4 mm thick, dyed brown) (National Research and Development Institute for Textiles and Leather Division Leather and Footwear Research Institute Bucharest, Romania).

- Biologic Material: Aspergillus niger.

Gas Chromatography Mass Spectrometry (GC/MS) Analysis:

*email: o_niculescu@yahoo.com 
Analysis of the essential oils carried out by using Agilent 7890 A GC System equipped with Agilent 5795 C MS, and HP-5 MS (0.25 mm x $30 \mathrm{~m}$ i.d., film thickness 0.25). The carried gas helium (99.9\%) at a flow rate of $1 \mathrm{~mL} / \mathrm{min}$; ionization energy was $70 \mathrm{eV}$. Mass range $\mathrm{m} / \mathrm{z}$ 50-650 amu. Data acquisition was scan mode. MS transfer line temperature was $250{ }^{\circ} \mathrm{C}$, MS Ionization source temperature was $230{ }^{\circ} \mathrm{C}$, the injection port temperature was $250{ }^{\circ} \mathrm{C}$. The samples were injected with 250 split ratio. The injection volume was $1 \mu \mathrm{L}$. Oven temperature was programmed in the range of 50 to $250{ }^{\circ} \mathrm{C}$ at $3{ }^{\circ} \mathrm{C} / \mathrm{min}$. The structure of each compound was identified by comparison with their mass spectrum (Nist 05 and Wiley 7 library) [16].

Attenuated Total Reflectance Fourier transform infrared spectroscopy (ATR-FTIR) measurements were run with a Jasco instrument (model 4200), in the following conditions: wavenumber range $-600-4000 \mathrm{~cm}^{-1}$; data pitch $0.964233 \mathrm{~cm}^{-1}$; data points -3610 : aperture setting $-7.1 \mathrm{~mm}$; scanning speed $-2 \mathrm{~mm} / \mathrm{s}$; number of scans -30 ; resolution $-4 \mathrm{~cm}^{-1}$; filter $-30 \mathrm{kHz}$; angle of incident radiation $-45^{\circ}$ [17].

Total amount of phenolic compounds in the essential oil, at a concentration of $400 \mathrm{ppm}$ in ethanol, was measured with a JASCO V-550 UV-Vis-NIR spectrophotometer.

The absorption was measured after $30 \mathrm{~min}$ at $20^{\circ} \mathrm{C}$, at $765 \mathrm{~nm}$.

Applying essential oil of cloves on leather samples was made by dropping 0.2, 0.4 and $0.6 \mathrm{~mL}$ oil and ethanol 1:1) on the surface of $2.0 \times 2.0 \mathrm{~cm}^{2}$.

The samples treated with essential oil and untreated were placed in each Petri dish in the center of the surface of the culture medium, then the culture medium was seeded in 3 points around the sample, as an equilateral triangle. Petri dishes were placed in thermo-hygrostat at $30^{\circ} \mathrm{C}$ temperature and were analized after 7, 14, 21 and 28 days.

The goal was to monitor the influence of the treatment applied to the sample on mold growth through the mold resistance under simulated contamination, according to no.12697/A 9:2008 „Finished leathers. Mold resistance testing" $[18,19]$.

Optical microscopy images were captured using a Leica stereomicroscope S8AP0 model with optic fiber cold light source, L2, with three levels of intensity, and magnification 40X [20].

Chemical characteristics of the uncoated leathers were determined according to the following standards: moisture (\%) - SR EN ISO 4684:2006; the content extractables (\%) - SR EN ISO 4648:2008; the content of chromium oxide (\%) - SR EN ISO 5398:2008.

\section{Results and discussions}

Identification of compounds in the composition of clove essential oil

Cloves essential oil was analysed using GC-MS [16].

Chromatogram for cloves oil is shown in Figure 1, and identification of compounds in their composition is presented in table 1 .

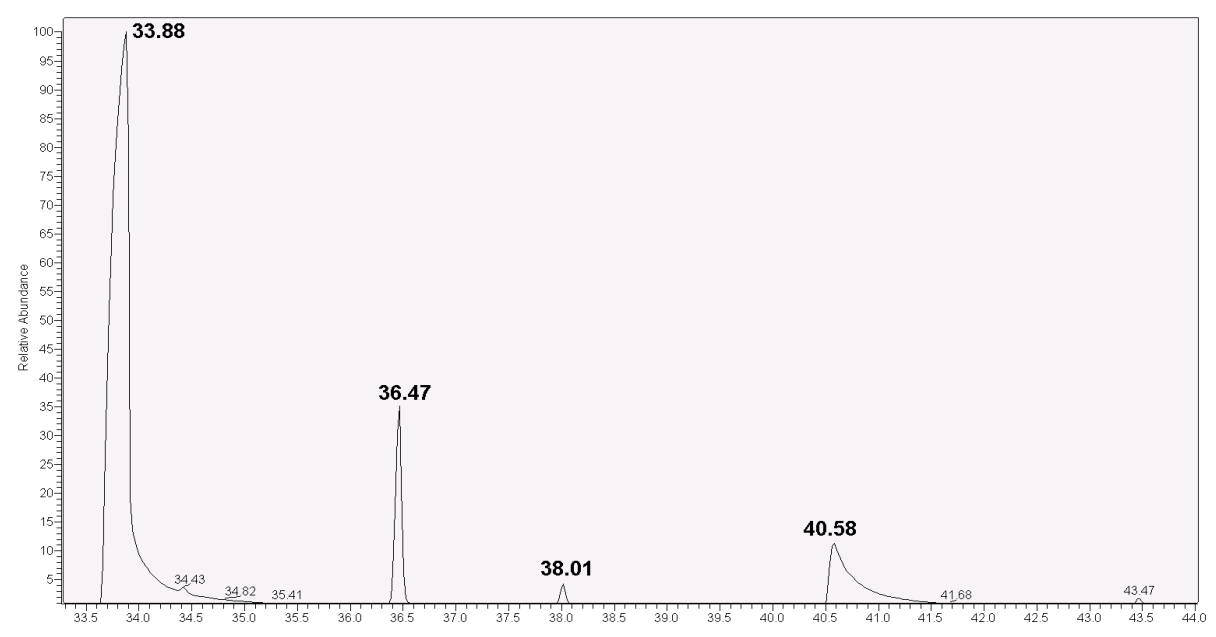

Fig.1. Chromatogram of organic compounds in the cloves essential oil

Table 1

IDENTIFICATION OF ORGANIC COMPOUNDS IN THE CLOVES ESSENTIAL OIL BY GC-MS

\begin{tabular}{|c|c|c|c|}
\hline No. & RT & Amount, $\%$ & Compounds \\
\hline 1 & 33.88 & 78.03 & Eugenol \\
\hline 2 & 36.47 & 9.46 & Caryophylene \\
\hline 3 & 38.01 & 1.08 & Alpha Humulene \\
\hline 4 & 40.58 & 10.93 & Aceteugenol \\
\hline 5 & 43.47 & 0.51 & Caryophylene oxide \\
\hline
\end{tabular}


The following compounds are found in the highest amount: eugenol $-78.03 \%$, aceteugenol $-10.93 \%$, caryophylene $-9.46 \%$ and alpha humulene $-1.08 \%$.

Cloves essential oil was analysed using FT-IR. [17]

FT-IR (ATR) spectra of cloves essential oil is shown in Figure 2.

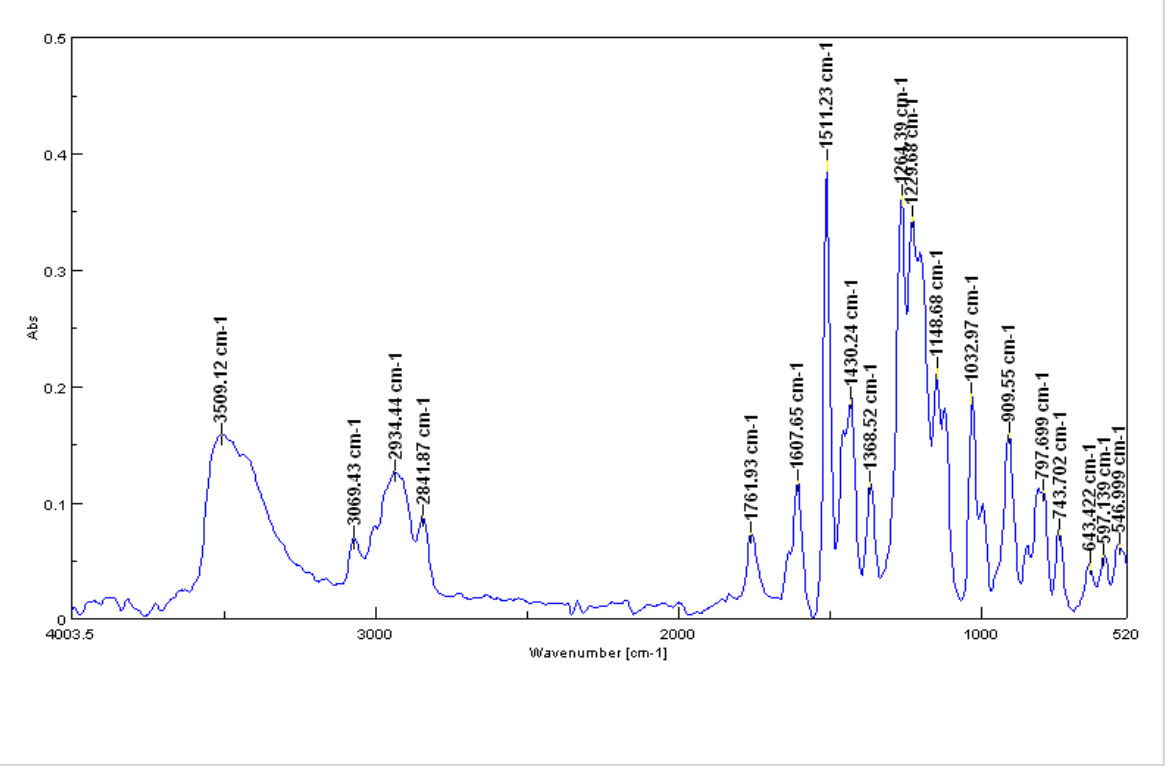

Fig. 2. FT-IR spectra of cloves essential oil

The main bands of cloves oil are (Fig. 2): 3509 and $2934 \mathrm{~cm}^{-1}$ - indicating the presence of aliphatic $\mathrm{CH}_{2}$ groups, $1607 \mathrm{~cm}^{-1}$ and $1761 \mathrm{~cm}^{-1}$ - indicating the presence of $\mathrm{C}=\mathrm{O}$ group from ester, 1430 and $1368 \mathrm{~cm}^{-1}-$ assigned to the $\mathrm{C}$ $\mathrm{H}$ group, $1264 \mathrm{~cm}^{-1}, 1229 \mathrm{~cm}^{-1}, 1032 \mathrm{~cm}^{-1}, 909 \mathrm{~cm}^{-1}$ given by the C-O-C group from ether.

Cloves essential oil was analysed using UV-VIS for determination of total amount of phenolic compounds.

UV-VIS spectra of cloves essential oil is shown in Figure3.

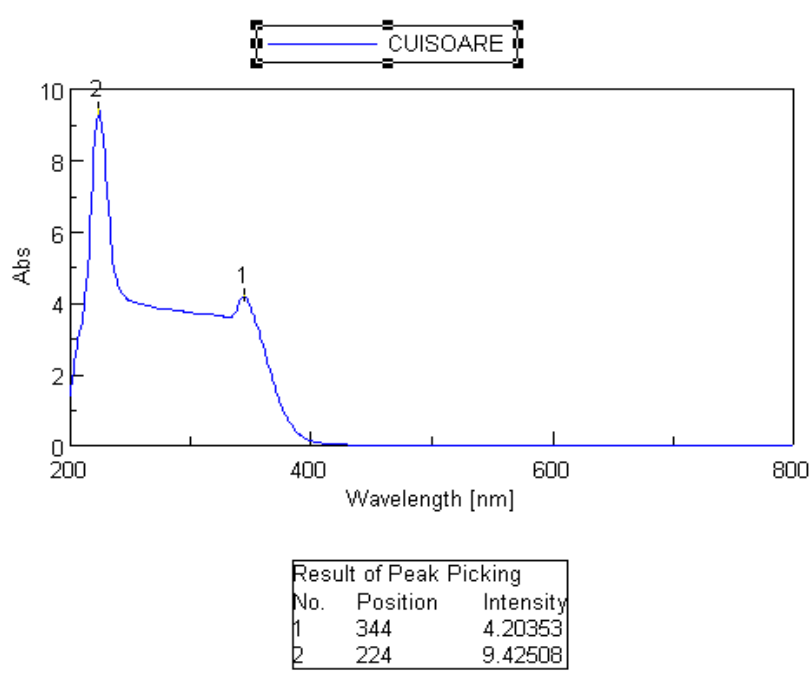

Fig. 3. UV-VIS spectra of cloves essential oil

UV absorption spectra of oil samples in ethanol show the presence of tannins, because the absorption peak observed at 200-280 nm is typical for condensed benzene ring system, in which conjugation is realized between aromatic group and carbonyl group, double bond, or hetero atom.

\section{Characterization by chemical analyses}

Chemical characteristics of the uncoated leathers used to obtain bovine hides into natural grain box determined in accordance with standards no. 1619:1994 (Table 2).

Chemical characteristics of the uncoated leathers were determined according to the following standards: moisture (\%) - SR EN ISO 4684:2006; the content extractables (\%) - SR EN ISO 4648:2008; the content of chromium oxide (\%) - SR EN ISO 5398:2008. 
Table 2

CHEMICAL CHARACTERISTICS OF BOVINE HIDES INTO NATURAL GRAIN BOX

\begin{tabular}{|c|c|c|c|c|c|}
\hline Sample/Characteristics & CLO-1 & CLO-2 & CLO-3 & M & $\begin{array}{c}\text { ST } \\
1619: 1994\end{array}$ \\
\hline Moisture, $\%$ & 14.85 & 14.55 & 14.24 & 14.28 & $14-15$ \\
\hline The content extractables, $\%$ & 7.12 & 7.68 & 7.39 & 7.87 & Max.8 \\
\hline The content of chromium oxide, \% & 5.44 & 5.14 & 5.65 & 5.85 & Min.3.5 \\
\hline
\end{tabular}

Chemical characteristics of the natural grain Box bovine are within the limits specified in standard.

\section{Biological characterisation of the leather samples}

The samples treated with different amounts of cloves essential oil on the surface of unifinished leather, CLO-1)0.2 $\mathrm{mL}$ oil and eyhanol 1:1), CLO-2 (0.4 mL oil and ethanol 1:1) and CLO-3 (0.6 mL oil and ethanol 1:1), were inoculated with biological material - Aspergillus niger spores.

Aspergillus niger spores were inoculated in three areas: right side, center and left side of the sample, according to the procedure specified in ASTM D 4576-86 „Standard test method for mold growth resistance of blue stock (leather)". Incubation was 28 days, but observations were also performed at 7, 14, 21 and 28 days [18, 19].

Aspergillus niger strain development was assessed by ranking: 0 - absence of stems and a strong fungitoxic effect, 5 - an almost non-existent effect (the mold covers the entire surface of the specimen). Mold development on leather specimens, and macroscopic images of samples treated with CLO-1-3, after 7, 14, 21 and 28 days from treatment, are presented in table 3.

The numbers under the images are the marks given according to the standard.

Table 3

MACROSCOPIC IMAGES OF SAMPLES TREATED WITH CLOVES ESSENTIAL OIL AFTER 7, 14, 21, 28 DAYS

\begin{tabular}{|c|c|c|c|c|}
\hline $\begin{array}{c}\text { Sample/ } \\
\text { day }\end{array}$ & 7 & 14 & 21 & 28 \\
\hline CLO-1 & & & & \\
\hline & 0 & 0 & 0 & 0 \\
\hline CLO-2 & & & & \\
\hline & 0 & 0 & 0 & 0 \\
\hline $\mathrm{CLO}-3$ & & & & \\
\hline & 0 & 0 & 0 & 0 \\
\hline Control & & & & \\
\hline & 2 & 4 & 5 & 5 \\
\hline
\end{tabular}


The cloves essential oil used to treat box bovine leathers, improves their quality and resistance to fungi and bacteria. Lwather samples CLO-1-3 do not develop fungi for 28 days - mark 0). Leather Control sample untreated with the cloves essential oil develops fungi, as shown by marks ranging between 2 after 7 days, 4 after 14 and 5 after 21-28 days.

\section{Conclusions}

- Essential oil isolated from cloves (Eugenia caryophyllata) containing: eugenol - 78.03\%, aceteugenol - 10.93\%, caryophylene $-9.46 \%$.

-The cloves essential oil used to treat box bovine leathers, improves their quality and resistance to fungi and bacteria, reducing the surface defects of natural skin caused by fungi and bacteria.

- The selected essential oil of cloves (due to the high eugenol content) can be used as an antifungal agent in the field of natural leather processing.

Acknowledgements:This works were carried out with the support of Nucleus Program, TEX-PEL-VISION 2022, 4N/8.02.2019/Act ad.1/2019, with the support of the Ministry of Research and Innovation, project number PN 19170201 /2019, and within Program 1 -Development of the national RD system, Subprogram 1.2-Institutional Performance-RDI excellence funding projects, Contract no. 6PFE / 16.10.2018.XS.

\section{References}

1. *** Directive 2010/75/EU of the European Parliament and of the Council of 24 November 2010 on industrial emissions ( integrated pollution prevention and control)

2. DESELNICU, V., DESELNICU, D.C., VASILESCU, A.M. and MILITARU, G. (2014), "EU Policy for Sustainable Consumption and Production - EU Ecolebal for footwear", Proceedings of the 5th International Conference on Advanced Materials and Systems ICAMS 2014, 23-25 October 2014, Bucharest, 641-646.

3. DESELNICU, D.C. (2014), European Policies for Products and their Relevance for the Footwear Sector (RO), ISBN: 978-973-720-555-1 (245pg), Agir Press.

4. http://www.europeana.ro/dosare/mediu.htm.legislatie.

5. NZEAKO, B.C., AL-KHAROUSI, Z.S.N. and AL-MAHROOQUI, Z., Antimicrobial Activities of Clove and Thyme Extracts, Sultan Qaboos University Medical Journal, 2006, 6(1), 33-39.

6. RADWAN, I.A., ABED, A.H., ABEER, M.R., IBRAHIM, R.A. and ABDALLAH, A.S., "Effect of thyme, clove and cinnamon essential oils on Candida albicans and moulds isolated from different sources", American Journal of Animal and Veterinary Sciences, 2014, 9(4), 303-314.

7. CHEEN, H.Y. and LEE, M.H., Antifungal Activity of Clove Essential Oil and its Volatile Vapour Against Dermatophytic Fungi, Mycobiology, 2007, 35(4), 241-243.

8. NICULESCU, O., LECA, M., MOLDOVAN, Z., DESELNICU, D.C., Obtaining and characterizing a product with antifungal properties based on essential oils and natural waxes for finishing natural leathers, Rev. Chim. (Bucharest), 66, no. 11, 2015, p. 1733

9. NICULESCU, O., DESELNICU, D.C., GEORGESCU, M., NITURCA, M., Finishing product for improving antifungal properties of leather, Rev. Pielărie şi Incălţăminte (Leather and Footwear J.), 2017, 1, p. 31-38.

10. SIRVAITYTE, J., SIUGZDAITE, J., VALEIKA, V., Application of commercial essential oils of Eucalyptus and Lavender as natural preservative for leather tanning industry, Rev. Chim. (Bucharest), 62, no. 9, 2011, p. 884.

11. European Pharmacopeia, vol. II, ESCOP Strasbourg, Council of Europe, 2005.

12. Farmacopeea Română, ediţia a X-a, Ed. Medicală, Bucureşti, 1998.

13. CONSTANTINESCU, D.G., HATIEGANU, E., BUSURICU, F., Plante medicinale utilizate în terapeutică, Bucureşti, Editura Medicală, 2004.

14. STANESCU, U., MIRON, A., HANCIANU, M., APROTOSOAIE, C., Plante medicinale de la A la Z, Iaşi , Editura Gr. T. Popa, 2004.

15. ARDELEAN, A., MOHAN, G., Flora medicinală a României, Bucureşti, Editura All, 2008.

16. DAVID,V., MEDVEDOVICI, A., Metode de separare şi analiză cromatografică, ediţia a II-a, Ed. Universităţii din Bucureşti, $2008,148$.

17. MOLDOVAN, Z., Metode instrumentale de analiză, Ed. Universităţii din Bucureşti, 2001.

18. ST 12697/A 91/2008, standard for determination of leather resistance to fungi.

19. ASTM D 4576-86, standard test method for mold growth resistance of blue stock (leather).

20. XXX-Manual de utilizare a microscopului optic.

Manuscript received: 13.03 .2019 